\title{
Correction to: Histopathological investigation of the reef coral Goniastrea sp. affected by macroalgal abrasion
}

\author{
B. Manikandan ${ }^{1} \cdot$ A. A. Padelkar ${ }^{1,3} \cdot$ J. Ravindran ${ }^{2} \cdot$ S. Joseph ${ }^{1}$
}

Published online: 25 March 2021

๑) Springer-Verlag GmbH Germany, part of Springer Nature 2021

Correction to: Marine Biology (2021) 168:44

https://doi.org/10.1007/s00227-021-03851-w

In the original publication of the article, the 2nd author affiliation has been changed to Department of Marine Science, Barathidasan University, Trichy-620024.

Publisher's Note Springer Nature remains neutral with regard to jurisdictional claims in published maps and institutional affiliations.

The original article can be found online at https://doi.org/10.1007/ s00227-021-03851-w.

B. Manikandan

manikandan@nio.org

1 Coral Reef Ecology Lab, Biological Oceanography Division, CSIR-National Institute of Oceanography, Dona Paula 403004, Goa, India

2 CMP Division, CSIR-Central Electrochemical Research Institute, Karaikudi 630003, Tamilnadu, India

3 Department of Marine Science, Barathidasan University, Trichy 620024, India 